\title{
Hidradenitis Suppurativa, Metabolic Syndrome, and Demodex spp.
}

\section{Infestation}

\section{Hidradenitis Supurativa, Metabolik Sendrom ve Demodex spp. Enfestasyonu}

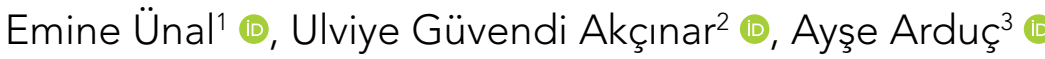

1Department of Dermatology, Ankara Yıldırım Beyazıt University, Yenimahalle Training and Research Hospital, Ankara, Turkey 2Department of Microbiology, Ankara Yıldırım Beyazıt University, Yenimahalle Training and Research Hospital, Ankara, Turkey ${ }^{3}$ Department of Endocrinology, Ankara Yıldırım Beyazıt University, Yenimahalle Training and Research Hospital, Ankara, Turkey

Cite this article as: Ünal E, Güvendi Akçınar U, ArduçA. Hidradenitis Suppurativa, Metabolic Syndrome, and Demodex spp. Infestation. Turkiye Parazitol Derg 2018: 42: 171-4.

\begin{abstract}
Hidradenitis suppurativa (HS) is a chronic inflammatory skin disease. This type of dermatosis with underlying chronic inflammation significantly affects the quality of life and may be accompanied by many comorbidities. In this case, Demodex spp. was associated with treatment-resistant and persistent course of skin diseases. A 46-year-old female patient applied to our clinic with complaints of lesions on the body and hip. Her dermatological examination revealed abscess formation and post-inflammatory pigmentation. Millimetric scar formation and improved folliculitis-like lesions were observed on both glutei. These complaints started 7 years ago and become more intense and severe by time. Owing to the diagnoses of diabetes mellitus, hypertension, and hyperlipidemia, the patient was monitored for metabolic syndrome. In the cultures taken from the lesions, no growth was seen. A standardized skin surface biopsy of the patient demonstrated demodicosis. The patient was treated with oral metronidazole and topical permethrin lotion, whereupon a pronounced recovery was observed in her clinical condition. In the light of this case, we recommend that patients with HS should be checked for the presence of Demodex spp., and if it is detected, an appropriate treatment should be applied. To our knowledge, this is the first case report presenting the relationship between $\mathrm{HS}$ and Demodex infestation.
\end{abstract}

Keywords: Hidradenitis suppurativa, obesity, Demodex spp., metabolic syndrome
Received: 03.04.2017
Accepted: 10.01 .2018
Çevrimiçi Yayın Tarihi: 08.03.2017

\section{ÖZ}

Hidradenitis supurativa kronik inflamatuvar bir deri hastalığıdır. Kronik inflamasyon zemininde gelişen bu dermatoz, kişinin yaşam kalitesini önemli derecede etkiler ve birçok komorbidite ile seyredebilir. Demodex spp, inatçı seyirli ve tedaviye dirençli deri hastalıkları ile ilişkilendirilmiştir. 46 yaş kadın hasta hasta kliniğimize gövdede ve kalçada yara şikayeti ile başvurdu. Dermatolojik muayenesinde gövdede abse formasyonu, postinflamatuvar pigment değişiklikleri izlendi. Her iki gluteada milimetrik skar formasyonu ile iyileşmiş folikülit benzeri lezyonlar izlendi. Bu şikayetleri yedi yıl önce başlamış ve giderek şiddetlenmişti. On yıldır Diabetes mellitus, hipertansiyon, hiperlipidemi tanıları olan hasta metabolik sendrom ile takip edilmekteydi. Yara kültüründe üreme olmadı. Hastaya standart yüzeyel deri biyopsi yapıldı ve Demodikozis saptandı. Hasta oral metronidazol ve topikal permetrin losyon ile tedavi edildi ve kliniğinde belirgin düzelme oldu. Bu olgu ışığında, Hidradenitis supurativa tanılı hastalarda Demodex spp. aranması ve tespit edilirse uygun tedavinin verilmesini öneriyoruz. Bu olgu hidradenitis supurativa ve Demodex enfestasyonu ilişkisini gösteren ilk bildirimdir.

Anahtar Sözcükler: Hidradenitis supurativa, obezite, Demodex spp., metabolik sendrom

Geliş Tarihi: 03.04.2017

Kabul Tarihi: 10.01.2018

Available Online Date: 08.03.2017

Corresponding Author / Sorumlu Yazar: Emine Ünal E.posta: eminesu83@gmail.com DOI: $10.5152 /$ tpd.2018.5330

CCopyright 2018 Turkish Society for Parasitology - Available online at www.turkiyeparazitolderg.org

(CTelif hakkı 2018 Türkiye Parazitoloji Derneği - Makale metnine www.turkiyeparazitolderg.org web sayfasından ulaşılabilir. 


\section{INTRODUCTION}

Hidradenitis suppurativa (HS) is a chronic inflammatory dermatosis characterized by recurring painful nodules and abscesses. The incidence rate is reported to be between $0.1 \%$ and $8 \%$ worldwide. HS may generally settle on the apocrine glands but at times on the whole body and glutei as well. The main mechanism of action for HS is based on follicular occlusion because of hyperkeratosis of the follicular epithelium, and follicular occlusion is followed by dilatation. Superinfection of the apocrine sweat glands is frequently seen but is not always detected. Chronic inflammatory reaction has been proven. HS is most commonly located in the axillary, inguinoperineal, gluteal, and submammarian regions, as well as in the nape of the neck and inner surface of the femoral area (1-3). Many patients are reported to be diagnosed late. Furthermore, they are commonly mistreated. HS may be accompanied by comorbid conditions such as insulin resistance, obesity, hypertension, diabetes, metabolic syndrome, depression, and inflammatory and autoimmune diseases. The frequency of skin cancer as a secondary condition to chronic inflammation on the skin has increased. Moreover, cardiovascular events are frequently observed in these patients (1-3). Smoking, increased body mass index, uncontrolled diabetes, not using any treatment for a long time, and late diagnosis have been reported as factors that increase the severity of HS $(1,2)$.

Demodex spp. is a mite belonging to the Demodecidae family of Prostigmata order of Arachnida class. A great majority of these mites are inevitable commensals in the pilosebaceous units of mammals such as cats and dogs. In humans, D. folliculorum and $D$. brevis are not only the most commonly reported types but also the most frequently detected ectoparasites. D. folliculorum and D. brevis are found in all humans regardless of race and sex. Demodex mites spend their whole lifespan in the hair follicles and sebaceous glands. When $\mathrm{pH}$ and heat conditions permit, this parasite continuously proliferates and maintains its chances of survival. Human-to-human infestation is facilitated by shared belongings and close contacts. In addition, this mite is reported to be found on everyone, and its positivity ratio increases proportionately to sebum rate with aging. Furthermore, there are reports stating that even if a person hosts Demodex spp., some certain genetic and environmental factors must also be met for Demodex spp. to in-

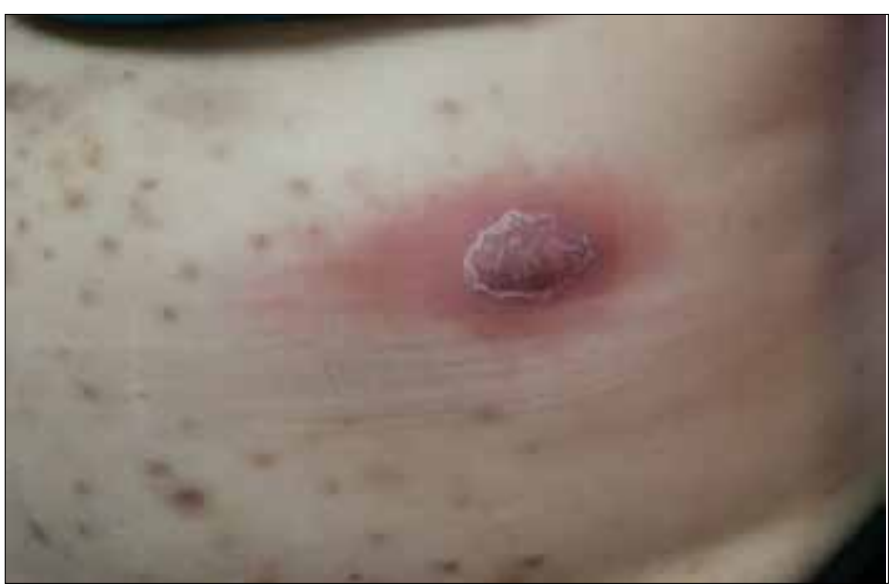

Figure 1. Abscess and post-inflammatory hyperpigmentation on the body duce diseases. For diagnosis, a cellophane slide, examining a skin scraping with potassium hydroxide, punch biopsy, and standard skin biopsy method can be used (4-6). The incidence of the diseases caused by Demodex mite is reported to increase in recent years. It is acknowledged worldwide that Demodex parasites may easily become pathogenic with the effect of some facilitating factors. Demodicosis can be seen as either a primary disease or a secondary one to an existing skin disease (4-6).

A case including a combination of HS and demodicosis is presented here. To our knowledge, this combination is reported for the first time in the literature.

\section{CASE REPORT}

A 46-year-old female patient applied to our clinic with complaints of inflamed acnes on the body and glutei. Owing to the diagnoses of diabetes mellitus, hypertension, and hyperlipidemia since 10 years, the patient was monitored for metabolic syndrome. Furthermore, considering her body mass index of 36 $\mathrm{kg} / \mathrm{m}^{2}$, this patient was advised a diabetic diet besides medical treatment. The patient, because of a diagnosis of diabetes, was also taking insulin and an oral antidiabetic. Since last 2 years, her glycated hemoglobin values have varied between $8.4 \%$ and 9.5\% on 3-month diabetic follow-ups. As treatment, the patient took insulin glargine $100 \mathrm{IU}(2 \times 30 \mathrm{U})$, insulin aspart $(3 \times 30 \mathrm{U})$, and oral metformin $\mathrm{HCl} 1 \mathrm{~g}$, as well as ramipril $5 \mathrm{mg}$ tablet $(1 \times 1)$ and atorvastatin $10 \mathrm{mg}$ tablet $(1 \times 1)$. The patient's skin-related complaints had started 7 years ago but become more intense and severe during the last 2 years. The patient was a half-pack-aday smoker since 30 years, but had not consumed alcohol. At an external center, the patient frequently and at different times used $500 \mathrm{mg}$ azithromycin, $300 \mathrm{mg}$ cefdinir, $297.88 \mathrm{mg}$ potassium clavulanate, $100 \mathrm{mg}$ doxycycline, $500 \mathrm{mg}$ ciprofloxacin, and various topical antibiotic treatments because of these lesions on the body and glutei. Moreover, the patient frequently used analgesic and anti-inflammatory drugs and was intra-articularly injected with triamcinolone hexacetonide twice because of epicondylitis of the elbow. Her dermatological examination revealed abscess formation and post-inflammatory pigment alteration (Figure 1). Millimetric scar formation and improved folliculitis-like lesions were observed on both glutei (Figure 2). We diagnosed this patient with $\mathrm{HS}$ in the light of these clinical findings. According to the Hurley clinical staging system, this disease was at stage 1 (7). In the cultures taken under appropriate conditions from the active pustular lesions on the body and glutei, no growth was observed. We took standardized skin surface samples from the chin and hip and detected 10 viable D. folliculorum per $\mathrm{cm}^{2}$ in the samples (Figure 3). The patient did not report any eye-related complaint, nor was any mite detected at the bottom of her eyelashes. Owing to its anti-demodectic and anti-inflammatory effects, oral metronidazole tablet treatment was started and continued every morning and evening for 20 days. The patient was advised to apply topical permethrin on the face, body, and gluteal regions once every night for 3 months. The patient started to use a gel wash containing $5 \%$ tea tree oil for the face (twice a day) and body (twice a week). A significant improvement was observed in the patient's pustular lesions by the end of the 3-month follow-upperiod. However, the disease could not be ful- 


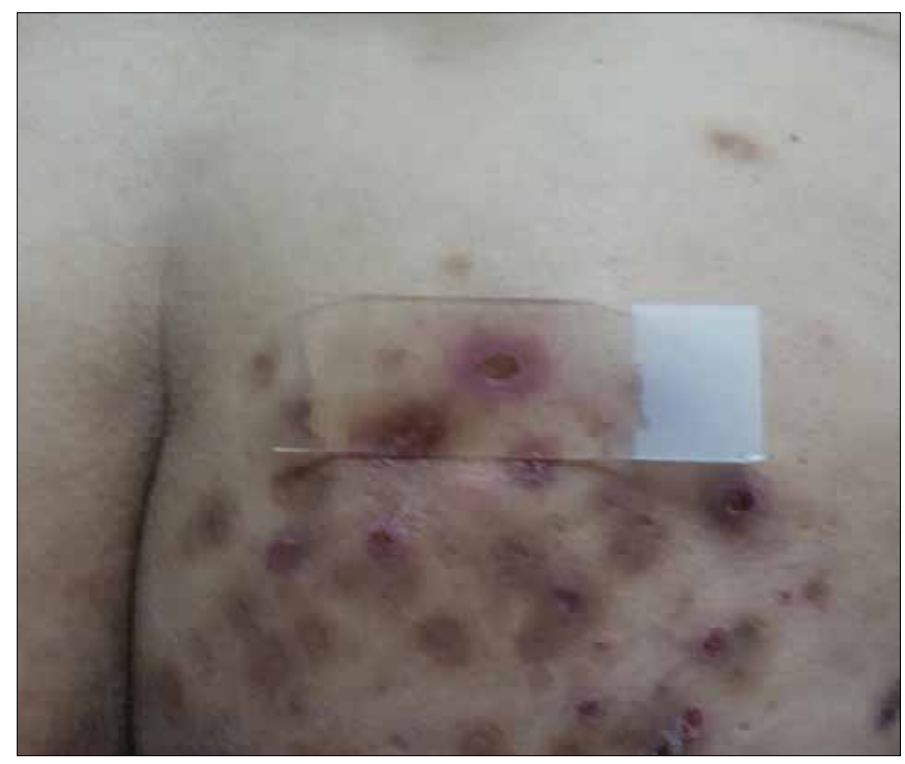

Figure 2. Millimetric scar formation and improved folliculitis-like lesions on both glutei

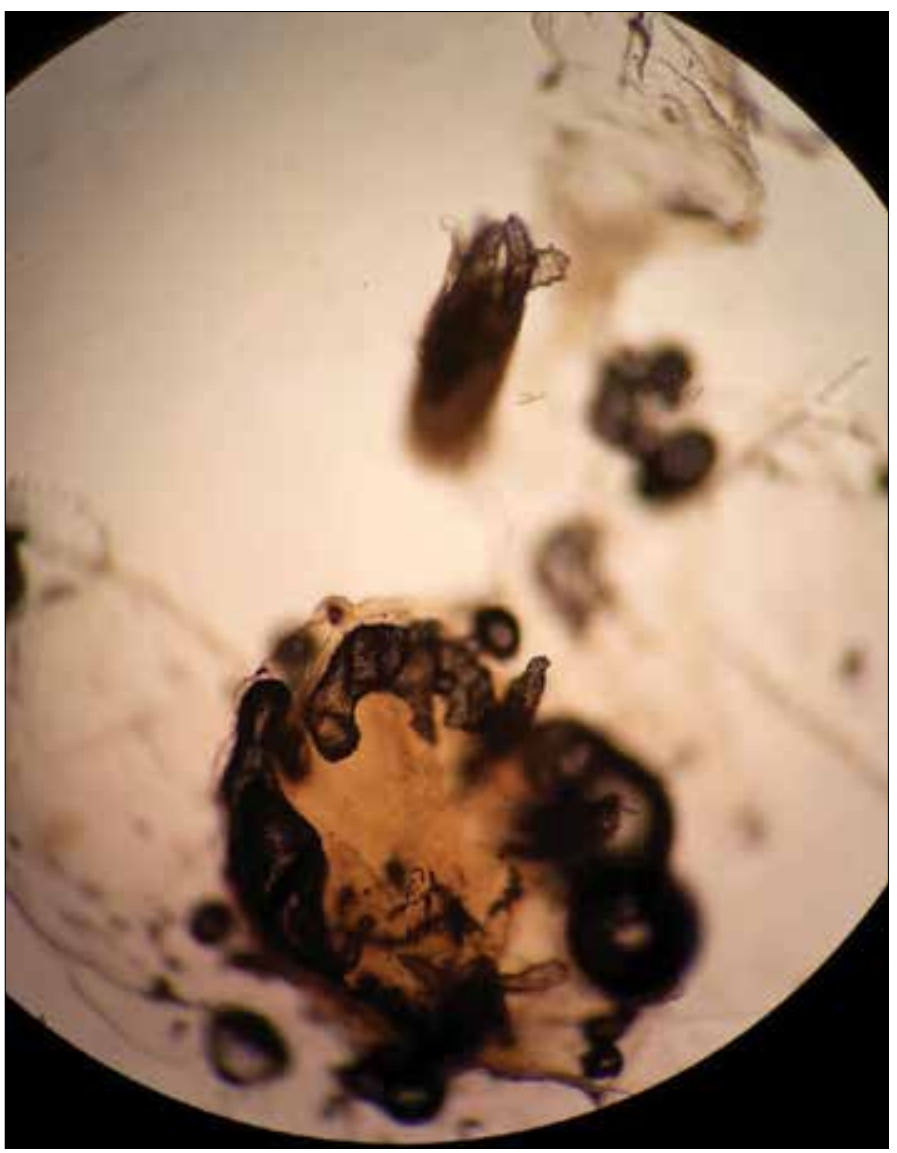

Figure 3. Demodex mites monitored on standard skin biopsy method

ly cured. It is our belief that included among the causes of failure in full response to treatment was the patient's failure in diabetes regulation, obesity, and continuing to smoke. Thepatient is still being monitored by us. Informed consent form was obtained from the patient.

\section{DISCUSSION}

The clinical significance of Demodex mites is acknowledged worldwide $(4,6)$. Demodex spp. stimulates the immune system and may cause chronic inflammation. In papulopustular and erythema telangiectasia rosacea, the increased release of serine proteases and Toll-like 2 receptors together with abnormal cathelicidins is demonstrated. It is also reported in the literature that immunological reaction may develop against Bacillus oleronius proteins carried in the guts of Demodex spp. (8). It is considered that chronic inflammation attributable to Demodex infestation may cause many diseases such as rosacea, blepharitis, perioral dermatitis, pustular folliculitis, papulopustular lesions on the scalp, pityriasis folliculorum, and basal cell carcinoma $(4-6,8)$. Alterations in the immune system because of pregnancy, diabetes mellitus, and obesity and local immunosuppression because of long-term usage of topical or systemic corticosteroids may lead the Demodex mites to be pathogenic (5). Our patient not only suffered from obesity and diabetes but also was a heavy smoker. Obesity and diabetes mellitus may be associated with increased levels of adipokines and pro-inflammatory cytokines, and these cytokines show deleterious impacts on the immunity, resulting in immunosuppression related to an increase in the density of Demodex spp. (5). It is suggested that smoking induces acne and HS by the induction of follicular hyperkeratinization (1-3).

The causal relationship of Demodex mites in HS may be attributed to several mechanisms. The mites can migrate from one follicle to another at a speed of 8-16 mm over $7 \mathrm{~h}$ in the dark. The female mites are thought to deposit their ova in the deeper areas of the pilosebaceous unit and may mechanically block the follicles, leading to distension and causing intrafollicular hyperkeratosis. The mite body is covered with a hard exoskeleton. The chitinous external skeleton of the mite may act as a foreign body, and when Demodex mites breach the epithelial barrier, their antigens influence the immune system of the host and induce a type IV hypersensitivity reaction $(6,8)$. Another mechanism may be that the waste products of Demodex mites and/or associated bacteria, such as Staphylococcus epidermidis and B. oleronius, may activate the elements of the innate immune system or stimulate the immune system through the mechanism of delayed hypersensitivity (8), and this hypersensitivity reaction may be the triggering factor for HS development and may trigger the disease activity.

In HS treatment, antimicrobial and anti-inflammatory agents are used. Although various treatments are applied, it is indeed hard to choose a long-acting drug leading to no comorbidity. Based on the severity of the disease, oral and topical antibiotics, biological agents, and surgical and laser treatments can be applied (1-3). During HS treatment, various systemic antibiotic treatments such as clindamycin, rifampin, moxifloxacin, ceftriaxone, ertapenem, and metronidazole, dapsone, triamcinolone, infliximab, adalimumab, and anakinra may be used. For fibrotic lesions, surgical treatments are recommended, and long-pulsed Neodymium: yttrium-aluminum-garnet laser and carbon dioxide laser are also useful $(9,10)$. Moreover, combined treatments specific to the patients may be planned. Long-term usage of topical and systemic antibiotics may cause comorbidity as a result of 
effects on the microflora in addition to antibiotic resistance (9, 10). Consequently, choosing a patient-specific HS treatment is extremely important.

For demodicosis treatment, oral and topical metronidazole and topical permethrin can be used. Topical permethrin is effective in reducing the density of Demodex spp., and the patient, after using topical permethrin for 2-12 months until Demodex spp. is normalized, may continue to use the same for 3 successive days in a week. Owing to its anti-demodectic effects, the inclusion of a washing solution containing $5 \%$ tea tree oil will increase the possibility of the treatment to be successful $(11,12)$.

Long-term usage of topical and systemic antibiotics in patients with HS may cause the formation of comorbidity as a result of affecting the microflora in addition to antibiotic resistance (9). Furthermore, unnecessary and long-term usage of antibiotics may induce demodicosis formation by affecting the flora. As a result, patients diagnosed with HS should be checked for Demodex spp.; if and when demodicosis is detected, metronidazole, which has a target-specific mode of action against Demodex spp., should be preferred. Our patient used various systemic antibiotic treatments. With the diagnosis of demodicosis, we started a target-specific anti-demodectic therapy. Our patient partially responded to the therapy covering the administration of oral metronidazole for 20 days and topical permethrin for 3 months. Our patient was 46 years old and was not diagnosed since 7 years. Metabolic syndrome, smoking, and obesity are factors that not only facilitate Demodex infestation but also affect the formation and severity of HS $(1,5)$. We still monitor our patient with topical permethrin.

\section{CONCLUSION}

Therefore, we consider that there is an important etiological relationship between these two conditions. Here, we presented a case of a female patient with metabolic syndrome and accompanying demodicosis who was diagnosed with HS.

Informed Consent: Written informed consent was obtained from patient who participated in this case.

Peer-review: Externally peer-reviewed

Author Contributions: Concept - E.Ü., U.G.A; Design - E.Ü.; Supervision - A.A., U.G.A.; Resources - E.Ü., U.G.A.; Materials - U.G.A.; Data Collection and/or Processing - E.Ü., A.A.; Analysis and/or Interpretation - E.Ü.; Literature Search - E.Ü., A.A.; Writing Manuscript - E.Ü.; Critical Review - E.Ü., U.G.A., A.A.; Other - A.A.

Conflict of Interest: No conflict of interest was declared by the authors.

Financial Disclosure: The authors declared that this study has received no financial support.
Hasta Onamı: Yazılı hasta onamı bu olguya katılan hastadan alınmıştır.

Hakem Değerlendirmesi: Dış bağımsız.

Yazar Katkıları: Fikir - E.Ü., U.G.A; Tasarım - E.Ü.; Denetleme - A.A., U.G.A.; Kaynaklar - E.Ü., U.G.A.; Malzemeler - U.G.A.; Veri Toplanması ve/veya İşlemesi - E.Ü., A.A.; Analiz ve/veya Yorum - E.Ü.; Literatür Taraması - E.Ü., A.A.; Yazıyı Yazan - E.Ü.; Eleştirel İnceleme - E.Ü., U.G.A., A.A.; Diğer - A.A.

Çıkar Çatışması: Yazarlar çıkar çatışması bildirmemişlerdir.

Finansal Destek: Yazarlar bu çalışma için finansal destek almadıklarını beyan etmişlerdir.

\section{REFERENCES}

1. Bettoli V, Naldi L, Cazzaniga S, Zauli S, Atzori L, Borghi A, et al. Overweight, diabetes and disease duration influence clinical severity in hidradenitis suppurativa-acne inversa: evidence from the national Italian registry. Br J Dermatol 2016; 174 : 195-7. [CrossRef]

2. Lim ZV, Oon HH. Management of Hidradenitis Suppurativa in Patients with Metabolic Comorbidities. Ann Dermatol 2016; 28: 147 51. [CrossRef]

3. Hofmann SC, Saborowski V, Lange S, Kern WV, Bruckner-Tuderman $L$, Rieg S. Expression of innate defense antimicrobial peptides in hidradenitis suppurativa. J Am Acad Dermatol 2012; 66: 966-74. [CrossRef]

4. Hay RJ. Demodex and skin disease - false creation or palpable form? Br J Dermatol 2014; 170: 1214-5.

5. Unal E, Akcinar UG, Basaran Y. Increased Density of Demodex Folliculorum May be Related to Additional Risk Factors. Arch Iran Med 2016; 19: 525-6.

6. Katsambas $A$, Dessinioti $C$. The changing faces of acne, rosacea, and Hidradenitis suppurativa. Clin Dermatol 2017; 35: 115-7. [CrossRef]

7. Hurley HJ. Axillary hyperhidrosis, apocrine bromhidrosis, hidradenitis suppurativa and familial benign pemphigus. Roenigk RK, Roenigk HH Jr, editors. Surgical approach. Dermatologic surgery. Principles and practice. Newyork, USA. Marcel Dekker Inc.; 1996. p. 623-45.

8. McMahon F, Banville N, Bergin DA, Smedman C, Paulie S, Reeves E, et al. Activation of Neutrophils via IP3 Pathway Following Exposure to Demodex-Associated Bacterial Proteins. Inflammation 2016; 39: 425-33. [CrossRef]

9. Bettoli $V$, Join-Lambert $O$, Nassif A. Antibiotic Treatment of Hidradenitis Suppurativa. Dermatol Clin 2016; 34: 81-9. [CrossRef]

10. Andersen RK, Jemec GB. Treatments for hidradenitis suppurativa. Clin Dermatol 2017; 35: 218-24. [CrossRef]

11. Aytekin S, Göktay F. Demodikosis. Türkiye Klinikleri J Dermatol-Special Topics 2015; 8: 35-41.

12. Tighe S, Gao YY, Tseng SC. Terpinen-4-ol is the Most Active Ingredient of Tea Tree Oil to Kill Demodex Mites. Transl Vis Sci Technol 2013; 2: 2. [CrossRef] 